DOI: http://dx.doi.org/10.12775/ths.2016.007

\author{
Jacopo D'Alonzo
}

Sorbonne-Nouvelle Paris 3

UMR 7597 (Laboratoire d'histoire des théories linguistiques)

Sapienza-Università di Roma

jacopo.dalonzo@gmail.com

\title{
Trần Đức Thảo: A Marxist Theory of the Origins of Human Language
}

\begin{abstract}
This paper will explore Trần Đức Thảo's (Từ Sơn, Bắc Ninh, September $26^{\text {th }}, 1917$ - Paris, April 24 ${ }^{\text {th }}, 1993$ ) work from historical, philosophical, and linguistic points of view. Most notably it will focus on Thảo's Recherches sur l'origine du langage et de la conscience (1973). According to Marx and Engels, Thảo argued that language was originally constituted during collective cooperative activities. And he also suggested that human specific skills appeared for the first time with the production of first tools. To him, language arose as gestural and verbal indication involved in task-oriented cooperative activities already in hominid societies. Trying to integrate Piaget's child development psychology with the findings of Spirkin's anthropology, Thảo described six stages of evolution of genus Homo.
\end{abstract}

Keywords: Marxism; Phenomenology; Origins of Language; Tool-Making; Social Cognition.

\section{Introduction}

The aim of this paper is to describe and discuss the hypothesis on the origins of human language suggested by Trần Đức Thảo. ${ }^{1}$ He wrote some

$1 \quad$ This paper represents the written version of a talk given at the International Workshop. Theory of Language and the Debate on Language Origins. (Trento, Department of Humanities, 18-20 November 2015). 
works devoted to linguistic and anthropological issues and his two most famous books, namely Phenomenology and Dialectical Materialism (PDM, published in 1951) and Investigations into the origins of language and consciousness (ILC, published in 1973), reveal the development of his theory on the origins of language. It is not the task of this paper to offer a detailed description of Thảo's theory. What has to be stressed is only that some assumptions of his theory remained untouched between 1951 and 1973. And, maybe, Thảo's thought might still be useful to evaluate and appreciate certain hypotheses on the origins of human language which have been set out in the last few decades.

Thảo was considered one of the most relevant scholars and experts of phenomenology during the 1940s and the 1950s. But since he is not so famous nowadays, a brief and succinct list of biographical indications does not result inessential. ${ }^{2}$ Thảo was born in Vietnam on 26 September 1917. Interestingly, in the very year of the Russian Revolution and, in this regard, one cannot forget that Thảo's life had been deeply and constantly influenced by the political ups and downs of the Eastern Block. From 1936 to 1951 he studied, wrote and worked in Paris. Simultaneously, he enjoyed the political activities of the Vietnamese anti-colonial movement and became a representative of the French Marxist intelligentsia. In the 1940s he became one of first scholars who directly studied the unpublished writings of Edmund Husserl (1859-1938) and, then, he was regarded as one of the most relevant experts of Husserl's philosophy. So he took part in a large debate on the relation between phenomenology and Marxism together with other authors such as Jean-Paul Sartre (1905-1980), Maurice Merleau-Ponty (1908-1961), Alexandre Kojève (1902-1968), Jean-Toussaint Desanti (1914-2002), and others.

Thảo's political engagement became stronger than the academic interests. After he published his first book in 1951, he decided to return to Vietnam to actively take part in the resistance against the French. In the early years, Thảo worked as a professor at Hanoi University and his writings of the period were focused on Hegelian philosophy and on the history of philosophy. In 1957 he expressed his scepticism about the method of reeducation. One cannot forget that it was the period of the De-Stalinization and political reformism in Communist countries, and that the Vietnamese Communist Party was adverse to any form of revisionism. As a consequence

2 For more details see Thảo (1986, pp. 1-11), Thảo (1993), Papin (2013), Giao (1988), Hémery (2013), Thảo (2004, 2013), and Feron (2014). 
of his criticism, Thảo was tried and sentenced, and his imprisonment lasted until 1961.

After he had left prison he was no longer allowed to write in Vietnamese. So he was forced to write in French and he consequently sent his writings to some French reviewers. Between the 1960s and 1970s he broke away from Husserlian philosophy radically. In this period, in fact, Thảo's aim was to suggest a materialist anthropological theory on the origins of human cognition. In this way, he started writing again several articles and a book on the origins of human language. During the 1980s the control procedure had been loosened thanks to the spirit of the general reformism of Perestroika. So Thảo restarted to take part in the Vietnamese political debate. In the meantime, he began to be even more interested in questions concerning logical methods. In 1991 he finally returned to France and died in Paris on 24 April 1993.

\section{Phenomenology and Dialectical Materialism}

PDM (Thảo, [1951] 1985) is divided into two parts. The first one La méthode phénoménologique et son contenu effectivement réel (The phenomenological method and its actual real content) was composed between 1942 and 1950. For the most part, that section contains a description of «the essential features of phenomenology from a purely historical point of view» (Thảo, [1951] 1985, p. XXI). In the last chapter of the first part, Thảo explained Husserl's concrete analysis of lived experience which Husserl had introduced in his unpublished works. In those pages, Thảo did not codify dialectical materialism as an alternative to Husserl's phenomenology and preferred to integrate Husserlian philosophy into Marxism. Thus Thảo suggested a sort of naturalization of Husserl's phenomenology (Benoist, 2013).

To Thảo, materiality (Dinglichkeit, matérialité) «is not merely a substrate indifferent to the significations which it bears» ([1951] 1985, p. XXIII) but rather it is the real infrastructure on which the intellectual superstructures are founded. ${ }^{3}$ So Thảo reinterpreted the Husserlian notion of lifeworld

\footnotetext{
In this way Thảo subscribed himself to the approach of the dialectical materialism. With regard to dialectical materialism see Jordan (1967) and Thomas (2008). With regard to the dichotomy between economic base and superstructures see $M E W$ 13: 1-11 (i.e. Preface to A contribution to the Critique of Political Economy, 1859); and Bottomore (1991, pp. 45-48), Harman (1986), and Tomberg (1969).
} 
(Lebenswelt, monde de la vie). ${ }^{4}$ It is the dimension of the sensible life, the real world in which we live and act. The lifeworld is the horizon in which the ideal forms of thought (ideologies, religions, philosophies, and so on) take place. As a result, to Thảo, the Husserlian transcendental Ego is the sensible embodied historical Ego.

To Thảo consciousness is nothing but nature becoming human in the real sensible life. According to him, the most relevant lack of Husserl's phenomenology concerned the awareness of the sensible origin of consciousness. And that lack depends upon the intrinsic dualism of Husserlian account. But Husserlian philosophy, Thảo continued, could be useful to describe animal cognition. So he applied the phenomenological theory of consciousness to animal kingdom. Instead, human cognition requires other theoretical tools and especially the theory of human history suggested by Karl Marx (1818-1883) and Friedrich Engels (1820-1885).

Thảo described animal cognition by evoking some recent scientific theories suggested by such scholars like Louis Charles Henri Piéron (18811964), Rémy Perrier (1861-1936), Kurt Sgonina (1914-1939), and Wolfgang Köhler (1887-1967). Interestingly, Thảo put in relation the scientific findings of those scholars with Hausserlian description of consciousness. To make this point clearer, it could be useful to remember the cognitive stages described by Husserl: impression, sensation, sensorial field, object-phantom, real object, real relation, image, representation, and concept. To Thảo, those stages correspond to the different degrees of intelligent behaviour which one may observe in animal kingdom. More specifically, each cognitive stage corresponds to the following organisms: protista, sponges, coelenterates, worms, fish, mammals, lower apes, anthropoids, and humans. The link between Husserlian description of the stages of consciousness and the chain of organisms entails the following sequence of behavioural development: attraction and repulsion, contraction, reflex displacement, locomotion, apprehension, detour and manipulation, intermediary, instrument, toolmaking, and language.

When Thảo described the structures of behaviour from coelenterates to humans, he constantly mentioned Jean Piaget's (1896-1980) theory about sensory-motor development of the child. In this way, Thảo implicitly assumed the "biogenetical fundamental" rule set out by Ernst Haeckel (1834-1919): the ontogeny recapitulates the phylogeny. Thus Thảo integrated Piaget's

For the notion of Lebenswelt in Husserl's late writings see Hua VI (i.e. The Crisis of European Sciences): XXIX, XXXIX; and Perreau (2010), Claesges (1972), Kerckhoven (1985), and Waldenfels (1971). 
insight into a more general theory of the evolution of consciousness. And, in this way, he implicitly recalled Merleau Ponty's account of embodied consciousness set out in La structure du comportement (1942) and in Phénoménologie de la perception (1945).

To Thảo ([1951] 1985, pp. 145-146), the development of behaviour depends upon the inhibition of most primitive conducts. In other words, a given manifestation of behaviour is the result of the inhibition of a simpler type of behaviour. What Husserl called consciousness is nothing but the reflex of a given mode of behaviour. So the awareness of both, the object and the self, is the result of the interaction between the physiology of a given organism and the environment instead of being the point of departure for a behavioural mode. In fact, the evolution of cerebral cortex marks the development of ever more sophisticated systems of inhibition. And that evolution changes the interaction with the physical environment.

\section{The first hypothesis on Language Origins}

To Thảo, the description of the manipulation, the instrument-making, and the tool-making may elucidate the three main stages of the evolution from anthropoids to humans. Among anthropoids, the systematic use of instruments (instruments) is already at work. In contrast to apes, anthropoids recognize the intrinsic, and not merely occasional, efficacy of instruments. Instead, apes can only manipulate some natural objects that they find in their environment if the occasional need so requires. After offering a description of the production of instruments among anthropoids, Thảo ([1951] 1985, pp. 163-164) introduced the next stage in the history of cognitive evolution. This stage corresponds to the discovery of the tool (outil). The main feature of the tool is that it can be produced, preserved and reproduced. But toolmaking emerged only with $\mathrm{H}$. sapiens.

Thảo's next step was to explain how human language arose from the general symbolic function that links sounds and meaning. One could observe that function in certain animal communication systems. So the faculty of language is nothing but the specialization of a more general faculty which one can observe among other mammals. A barking dog shows the simplest communication system. The barking is an expression whose meaning is sketched out by the barking itself. In this way, the barking dog anticipates and signifies its own intention to attack. Insofar the dog inhibits the attack and sketches it out. For this reason, Thảo's position might be summarized in a brief sentence: "the symbolic act of signification is an act 
that stops at the initial phase of its accomplishment and refers, thereby, to its total form that has been left unaccomplished" (Thảo, [1951] 1985, p. 166). A communicative act requires two subjects (the ego and the alter-ego) at least. They reciprocally display partial communicative acts. Not only did the circle of communication starts with the communicative act of the ego, it also needs the understanding and the corresponding reaction of the alter-ego. And the communicative circle ends when the ego understands that the alter-ego has understood the first step of that circle. And Thảo described such a circle as "an exchange of intentional acts of reciprocal understanding, each affecting the other in the very same manner in which he himself is affected: the other affects me by means of the affect by which I have affected him" (p. 167).

Among anthropoids, and in particular among chimpanzees, the symbolic function takes the shape of the simulation: the symbolic act is, alone and in itself, regarded as meaningful and for this reason it could be employed to hide the real intentions of the actor. So the simulation is a communicative act that employs behaviour to achieve goals which are not immediately meant by the behaviour itself. According to the findings of Meredith Crawford (19102002), chimpanzees might take advantage of vocal signs although they cannot reach the level of human language. Language in strict sense is characterized by the fact that it involves concepts. Concepts are the historical products of both the social life within a given community and the intergenerational transmission of habits. In detail, Thảo insisted that language and concepts arose in the context of common goal-oriented and cooperative activities (tool-making) among our human ancestors.

To him, during tool-making activities, vocalizations rhythmically accompanied the same step of a given sequence of movements. Progressively, vocalizations allowed the internalization of the bodily-schemata involved in the sequence of movements. Then the interjections performed during common goal-oriented actions began to refer to bodily-schemata of that common activity. Those vocalizations became the first linguistic roots and they were the same for all members of the group. Likewise, everyone understands the same meaning when a given member pronounced those vocalizations because the group shares the same joint attentional frame as well as the same frame of reference. Remarkably, original linguistic signs were performed unintentionally. So Thảo did not agree with Engels's description of the origins of human language. To Engels, indeed, language is the result of the need to communicate ( $M E W 20$, pp. 444-455.). 


\section{The Language of Real Life}

Between 1974 and 1975 the French review La Nouvelle Critique published, in two parts, Thảo's article entitled "De la phénoménologie à la dialectique matérialiste de la conscience". Although that article chronologically followed the publication of Thảo's $I L C$, it could be regarded as an introduction to some issues which Thảo had discussed in his $I L C$. "De la phénoménologie" reveals Thảo's interest in Ferdinand de Saussure's (1857-1913) linguistics. At the time, indeed, Thảo's main aim was to suggest a semiotic theory which allowed him to describe the origins of human language. And his account differed from Saussure's regarding the role played by non-totally arbitrary signs. Insofar Saussure ([1916, 1995] 1959, pp. 67-69) had established that semiotics must study only the arbitrary aspect of signs, Thảo stressed the importance of investigating the motivated aspects of signs.

So Thảo introduced the project of a semiotics that he called "dialectical semiology" or "semiotics of the language of real life" whose object is the "general system of intrinsic or aesthetic signs". Thảo's notion of intrinsic signs is the starting point of his semiotic and linguistic proposal. That notion could be regarded as the antidote to Saussurian excessive reliance on the notion of arbitrariness. To clarify, Thảo insisted that nowadays there are signs - such as miming, gesturing, pointing, rites, symbols, figurative processes, artworks, gestural movements, pantomimes, facial features, and so on - whose meaning depends upon the intrinsic and sensible expressiveness of the signifier. So Thảo introduced the "material semiotic movement" as the peculiar semiotic dynamic system composed of intrinsic signs and involved in the social praxis. The system of intrinsic signs is the condition for having the general system of arbitrary signs described by Saussure. Insofar intrinsic motivated signs exhibit their own meaning at the sensory level, they support the invention of more abstract systems of arbitrary signs such as scientific languages.

Thảo invoked the notion of the language of real life in order to explain how language initially took the shape of a pragmatic instrument of social intercourse. According to Marx and Engels ( $M E W$ 3/11, pp. 26, 30-31), Thảo $(1974,1975)$ called the system of intrinsic signs "language of real life" (Sprache des wirklichen Lebens, langage de la vie réele). The German philosophers wrote that ideas, conceptions, and language arise from concrete social relations. To Thảo the language of real life can be seen as material vocal and gestural expressions involved in work activities. So it cannot be regarded as an already fully-formed language but rather as a collective semio- 
cognitive infrastructure involved in cooperative collaborative activities. And in this way, the language of real life must be seen as a pattern of the protolanguage employed by our ancestors.

Like Marx and Engels, Thảo added that human-specific cognition must be seen as a social product because it arises as a result of the internalization of social praxis by way of the language of the real life. Before the individuals employ the language of real life as a tool to communicate their own experience, the language of real life has the shape of a social fact that exists outside individuals. Almost the same was argued by the Russian psychologist Lev S. Vygotskij (1896-1934), even if Thảo never quoted him. Thus, to Thảo, the evolution of language, too, proceeds from the collective to the particular.

\section{The Second Hypothesis on Language Origins}

In PDM, language played a role, but not a very relevant one, because it was simply the mental reflex of social praxis. Thảo's perspective changed in his ILC: the language is no longer a reflex of social life but rather one of the most essential elements of social praxis. So Thảo dealt with the three main stages of the evolution of the language of real life - pointing, syntax, and fully-formed language. There are no clear-cut distinctions between these three stages but proximate overlaps, slow transitions and coexistence.

To explain the evolution of language, Thảo described the interactions of some elements: physiology and anatomy, communication, tool-making, cognition, social relations, and environment. So Thảo's theory of language evolution in his ILC seems to be more similar to Engels' view rather than to the theory set out in PDM. In 1951 Thảo explained the origins of human language without taking into account the evolution of humans: linguistic skills arose among our fully-formed human ancestors. To Engels, in contrast with that, the evolution of humans reveals a gradual development of anatomy (hands, brain, and senses), social life (labour, communication), and cognitive skills (language and consciousness). Each factor influenced the others and vice versa and language progressively evolved together with the other factors. In the same way, Thảo's ILC chronicled the slow evolution of both, language and cognition, and their interactions with the social and physical environment. In addition, he linked the stages of human evolution with the corresponding phases of child development as they had been discussed by Piaget and Thérèse Gouin-Décarie (1923- ).

To Tha o tool-making is the most decisive factor in the evolution of language. To him anthropoids already use "natural instruments" as objects 
which satisfy immediate needs. Instruments of this kind are the result of the individual "work of adaptation". The preparation and use of natural instruments take place in front or beside the biological object and are abandoned when the need disappears. Similarly, the communication systems of apes and anthropoids, such as "cries" and "simple indications", refer to the emotional aspect of the immediate situation. Thảo called signs of this kind "signs of presentation".

Instead, language of hominids was composed of the repetition of a set of indicative gestures and vocalizations which referred to absent objects. In this regard, the evolution of the hand had considerably changed the living condition of our ancestors. During the recession of tropical forests towards the end of the Tertiary Period (2, $58 \mathrm{ma})$, Thảo wrote that the first examples of australanthropus began to live in groups and worked in coordination to survive and adapt themselves to new environmental conditions. The australanthropus "prepared and conserved instruments" and got the means of subsistence from "collective hunting". Those cooperative activities required a certain distance between individuals and, as a result, the australanthropus displayed guidance gestures. Such a conclusion echoes the results of the Russian psychologist A. Spirkin (1918-2004). Guidance gestures were firstly referred to as objects that were perceptible in the environment. Since the systematic use of guidance gestures had been established, those signs began to indicate absent objects of biological needs and entailed the cognitive representation of them. To Thảo guidance gestures were simultaneously composed of motions of the hand along with cries. In the second chapter of the book signs of this kind were called become "signs of representation" (Thảo, [1973] 1984, p. 59) and "syncretic word" (70).

Before the Oldowan phase (ca. 2, 6-1, $7 \mathrm{ka}$ ), "elaborated instruments", or Kafuan instruments, were produced with the systematic help of another tool. The new working situations required a "straight-line gesture" which served to indicate the current work-object as well as everything interesting that could function as a possible work object. Signs of this kind were called by Thảo «typical name available to the group» (Thảo, [1973] 1984, p. 126). Hominids systematically used signs of representation such as guidance gestures and straight-line gestures. This fact involved the internalization of those signs. This dynamic corresponds to the neurophysiological process which fixes in the brain the traces of a given social habit. This is the first step of the specific ability to abstract away from a concrete situation that one can observe in humans. Hominids began to point out straight-line gestures to each other. And this use of gestures was the condition for having complex interpersonal relations («relation of reciprocity»). 
The social origin of that communication system (language of real life) developed a shared point of view that Thảo ([1973] 1984, pp. 12-13) called "collective cognizance". This one preceded the self-awareness of each individual as such.

The internalization of the language of real life involved self-awareness and "inner language". And inner language considerably increased the cognitive skills of our ancestors. So cognitive skills - such as the ability to abstract, self-awareness, social cognition, and so on - are the result of social interactions because they depend upon collective cooperative activities.

Thảo's purpose was to establish the cognitive function of "syncretic words" - i.e. the intrinsic signs which were simultaneously composed of vocalizations and gestures. Syncretic words, he insisted, had allowed the most elementary representation of the "confused form" of the object. For this reason he called syncretic words "functional names". Thảo's next step was to describe the transition from the functional name to the typical name which took place during the Kafuan Period (Lower Paleolithic, 2, $6 \mathrm{ma}-300 \mathrm{ka}$ ). To him, the typical name involved a form of representation of the object that he calls «typical image» (Thảo, [1973] 1984, p. 99): this representation could be regarded as a prototype of a group of objects and, to be clear, it should not be confused with the abstract concept. The typical image served, for instance, as a model for the reproduction of instruments. So Thảo emphasised that the archaeological evidence shows a standardization of the elaboration of instruments during the Kafuan Period.

Australanthropus began to connect two syncretic words with the help of the connection of the two subjacent gestures. And only when the stage of the australanthropus came to a close, the development of the lateral tubercle (Broca's area) entailed "the inhibition of sounds immediately after their emission which allows one to differentiate them by passing distinctly from one to the other" (Thảo, [1973] 1984, 55-56). Then spoken language became ever more pervasive. Thảo insisted that collective hunt in small groups required a communication system which was less equivocal than isolated syncretic words. Indeed syncretic words were extensively polysemous and thus they were understood only within a given perceptive field. H. habilis $(2,5-2,5 \mathrm{ma})$ began to systematically link typical names in order to produce elementary sentences, the so-called "functional sentences" (Thảo, [1973] $1984,82)$. The need to communicate among sub-groups played the leading part in using a more efficient communication system during a collective hunt. Such communication did not present sentences in a strict sense, which are defined by syntactic linking, but performed the same function by referring to relations between things. 
During the Oldowan Period (2, 6-1,7 ka), functional sentences were used to represent an absent scene instead of drawing attention to single objects or prototypes. Slowly, H. habilis began to connect elementary functional sentences in order to express the so-called "developed functional sentence". Slowly, a quantitative mechanical process increased the level of the syntactic complexity. To Thảo there was no qualitative gap between sentences of $\mathrm{H}$. habilis and those of H. sapiens. To him, the development of ever more complex syntactic constructions began with a three-terms fundamental structure: "this here (T) in a motion (M) in some form (F), or TMF". Together, those three terms (T, M, and F) represent the fundamental keys to produce almost all the sentences until a fully-formed language emerges. Interestingly, it seems that Thảo did not essentially separate the development of the syntaxsemantics interface.

Before the age of $\mathrm{H}$. neanderthalensis (200 ka - $40 \mathrm{ka})$, language was already fully-formed. At the beginning of the Chellean Period $(\sim 1,7 \mathrm{ka})$, the pithecantropus $(1 \mathrm{ma}-7000,000)$ revealed the ability to have, in advance, the representation of the long series of operations involved in tool-making (biface). Simultaneously, functional sentences became "sentences in the strict sense". They were nothing but the result of the connection of two or more sentences. Thảo's considerations might recall the cognitive and practical analogy between instrument-production and syntactic structures suggested by Leroi-Gourhan (1964-65). Thảo, however, did not explicitly suggest that sentences and operative chains had the same structures.

\section{Conclusions}

Historians of linguistic ideas have rarely paid attention to Thảo's linguistic theory (some exceptions are Baribeau, 1986; Barthes, 1951 (about his philosophy); Federici, 1970; McHale, 2002; Herrick, 2005). Thảo's hypothesis, however, deserves a special mention. The above examination of Thảo's major works would seem sufficient to effectively summarise the meaning of his theory of the origins of human language. In detail, Thảo's ILC took up the questions which were left open in his first book: How did language evolve from non-language? How did stimulus-bound animal communication become symbolic? Which of human ancestors already possessed some form of language? These questions are the same that are at the heart of the current debate on the origins of language (Pleyer, 2011).

Certainly, Thảo's theory, as has been seen, was deeply influenced by contemporary ideologies. Nonetheless, his perspective can serve as 
a touchstone by which the current proposals may be judged. Just to mention one example in this regard, Tomasello et al. $(2005,690)$ basically continue along the same line as Thảo. According to Tomasello, the evolution of language lies in the evolution of the ability for shared intentionality that enables us to develop a shared point of view as well as shared goals, plans, and intentions in cooperative activities within a joint attentional frame and a shared frame of reference. To Thảo, however, the ability for shared intentionality is the prerequisite of individual intentionality rather than being its development. Additionally, the evolution of that ability depends upon the need to cooperate rather than being the condition for having cooperation.

At the same time, Thảo's theory posed a challenge to Marxism: could dialectic materialism successfully explain the origins of language? So Thảo rigorously pursued the implications of dialectical materialism to focus on the heuristic potentialities of that insight. To him, dialectical materialism gave the best explanation for the social origins of language without transcending the natural dimension. To him, language faculty is located in the brain and depends upon some bodily predispositions. But this does not mean that language evolved in the brain alone. The fact is that language is first and foremost a social praxis. So it is shared by a group within the concrete and material horizon of labour. Thảo meant by labour the process encompassing all the cooperative collaborative activities necessary for the production of the means of subsistence. And the language of real life was indissolubly bound to labour.

Thảo's emphasis on labour (collective hunting, tool-making, etc.) makes his theory like those of many recent scholars such as Lieberman (1984), Burling (1999), Arbib (2005), Stout (2008), and Bickerton (2009). According to Thảo, tool-making must fulfil a dual task, to be the heuristic principle to deduce the cognitive skills of our ancestors and to be the explicative principle of the evolution of social habits. On the one hand the archaeological discoveries reveals the way the mind of our ancestors worked and on the other hand the evolution of practical skills involved in tool-making is the point of departure to suggest a hypothesis on the evolution of language. In other words, Thảo argued that cooperative hunting, social learning, toolmaking, and faculty of language share the same cognitive background. From this point of view, he suggested something similar to what has been set out by some recent scholars such as Gärdenfors (2003), Osvath and Gärdenfors (2005), and Spelke (1990; 2000).

The idea Thảo developed in this way was based on the assumption that language is a social tool. So Thảo focussed squarely on the fact that language is something that a given individual could find in the social 
environment. In fact, the language of real life might be regarded as a social tool shared by a group during cooperative collective activities. This language could be internalised by individuals and, thus, entails self-consciousness. So the language of real life become a way of expressing something that is characteristic of a particular person. It must be said that Thảo did not dismiss the role played by the extra-linguistic context insofar he explained how communicative acts could be meaningful. For these reasons, Thảo's theory may recall some assumptions of externalism (Parent, 2013) and the token-reflexive approach (Reichenbach, 1947). Language and other communicative acts, indeed, must be studied against the background of real communication. And that background is nothing but the pragmatic and physical frame of reference. To Thảo, cognitive and linguistic processes are rooted in physical interactions of the body with the physical and social environment. Instead, recent theories of embodied cognition seem to neglect the role of social environment (as Borghi and Cimatti, 2015, have already remarked).

For those reasons, Thảo's theory meets the need of an interdisciplinary approach in the field of the research on the evolution of language. Tha acknowledged that research on that topic must be intimately related to the findings of biology, too, as today it is widely accepted by the scientific community. (Fitch, Hauser and Chomsky, 2005, p. 180). Interestingly, he had, however, a peculiar idea of biology which was extensively influenced by Trofim D. Lysenko's (1898-1976) epigenetic model (Levins and Lewontin, 1985). Thus not only did Thảo suggest that the development of the brain could entail the evolution of language, he also set out that language, in turn, may change the brain and the corresponding cognitive skills. Nowadays, this dynamic is called co-evolution of brain and language (Deacon, 1998, p. 113). But nobody should forget that to Thảo the social praxis mediates the mutual influence of language and brain.

In contrast to many today's scholars, Thảo previously provided a general semiotic theory to support his hypothesis. This approach avoids the danger of the highly variable terminology which can be seen in several current studies. In detail, Thảo refused to merely condemn the non-wholly arbitrary signs, insofar they permit to suggest a hypothesis on semiogenesis of language. So he preserved the term sign in order to explicitly deprive it of all the privileges accorded it by scholars who regard a fully-formed language as a model of any semiotic system. Thus the question facing Thảo in his ILC was how a fully-formed language evolved from what, nowadays, Bickerton (1998, p. 341) calls protolanguage. Thảo, thus, seems to advocate a form of continuity approach (Pinker and Bloom, 1990; Pinker and Jackendoff, 2005). By virtue 
of this, he correspondingly described the evolution of linguistic skills among all symbol-using species in the Homo lineage (just like Deacon, 1998, p. 340f.). It is significant that, according to Thảo, the development of labour marks the most relevant shift between humans and other animals.

Thảo's semiotics offers some tools to assess some assumption which are extensively employed by recent scholars. For instance, Clark and Brennan (1991) use the terms "joint attentional frame" or "common ground" to describe that which gives a pointing gesture its meaning. Thảo would not have agreed with this definition. According to him, the joint attentional frame does not really work as something brought in from the outside. The pointing gestures are already meaningful. In fact, Thảo's genetic semiotics is based on the revaluation of motivated signs. And for this reason, motivated signs involve joint-attention rather than being determined by it. Indeed pointing gestures are displayed to draw attention to a specific situation within collective cooperative task. They are nothing but cooperative pointing gestures.

Thảo's emphasis on the peculiar semantic and syntactic features of gestural communication systems - which could be at best punctuated with grunts and other vocalizations - may recall Corballis (2003). To Thảo, the development of a fully-formed language follows a slow process that has led the original holistic communication system to the analytical structure of modern languages. Mithen (2005) has recently suggested something like that but he does not set out that holistic communication of our ancestors could be regarded as the only precursor of a fully-formed language. This fact reveals one of the main conundrums of Thảo's theory: How the development of the linear analytical order of words could explain the recursive procedures of fully-formed languages? Indeed Thảo was interested in the interactions between semantics and syntax rather than in the evolution of syntactical structures as such. For this reason it seems that he suggested a theory of the iconic nature of syntax (Burling, 1999).

For the same reason one may ask if the processes of internalisation and abstraction described by Thảo could explain the transition from motivated referential syncretic words to arbitrary signs. Thảo's answer was that this process did not end in a prehistoric phase but rather continues in everyday life. Motivated signs constantly support the conventional construction of systems of arbitrary signs. To Thảo, the most elementary understanding of a given speech act is enabled by the motivated features of communication (gestures, mimics, syntax, intonation, etc.), the frame of reference, and shared practical purposes.

The previous comparison between Thảo's theory and the current trends of the research on the evolution of language should not be taken as an attempt 
to legitimize the Vietnamese philosopher. Against that, we would regard Thảo neither as a naïve forerunner nor as a brilliant visionary. A given theory set out in the past must be seen as a historical phenomenon. But it does not mean that such a theory cannot offer valuable insights on how it is best to proceed for tackling current issues. Indeed the evolution of language is a field of research that cannot neglect the problematic nature and weakness of its methods, paradigms, and assumptions. Today, for instance, the main trend of that field of research should be interdisciplinary in nature. A crossdisciplinary type of research must suggest principles that would allow to connect data from different disciplines. But the principles which have been suggested so far need to be discussed further on because they still lack a shared common framework. Consequently, nobody can reject ancient theories in advance insofar as they may enable the debate to focus on the plausibility and potentialities of currently available assumptions.

\section{References}

With the abbreviation Hua is here indicated Husserliana. La Haye: Nijhoff; Dordrecht, Boston, London: Kluwer.

With the abbreviation $M E W$ is here indicated Marx-Engels-Werke. Berlin: Dietz Verlag.

Arbib, M. A. (2005). Beyond the Mirror: Biology and Culture in the Evolution of Brain and Language. Oxford (CN): University Press.

Baribeau, J. (1986). The provocative Tran Duc Thao theses. On the Origin of Language and Consciousness. A Review Essay. Science and Nature 7/6: $56-62$.

Barthes, R. (1951). Phénomenologie et matérialisme dialectique. Combat, 11 octobre 1951.

Benoist, J. (2013). Une première naturalisation de la phénoménologie?. In Benoist and Espagne (eds.) (2013: 25-48).

Benoist, J., Espagne, M. (eds.). (2013). L'itinéraire de Tran Duc Thao. Phénoménologie et transfert culturel. Paris: Armand Colin.

Bickerton, D. (1998). Catastrophic evolution: The case for a single step from protolanguage to full formed language. In Hurford, R., James, StuddertKennedy, Michael, Knight, Chris (eds). Approaches to the Evolution of Language: Social and Cognitive Basis, 341-358. Cambridge: University Press.

Bickerton, D. (2009). Adam's Tongue, Hill and Wang.

Borghi, M. A., Cimatti, F. 2015. WAT (Words As social Tools): Una prospettiva socio-corporea della cognizione umana. Sistemi intelligenti 2015 (2): 361-372. 
Bottomore, T. (ed.). (1991). A Dictionary of Marxist Thought. Malden (MA): Blackwell Publishing.

Burling, R. (1999). Motivation, conventionalization, and arbitrariness in the origin of language. In B.J. King (ed.). The Origins of Language: What Nonhuman Primates Can Tell Us, 307-350. Santa Fe, NM: School for American Research Press.

Corballis, C. M. (2003). From Hand to Mouth: The Origins of Language. Princeton: University Press.

Claesges, U. (1972). Zwischendeutigkeiten in Husserls LebensweltBegriff. In Claesges, Ulrich and Heid, Klaus (eds.). Perspektiven transzendentalphänomenologischer Forschung, 85-101. Den Haag: Nijhoff.

Clark, H. Herbert, Brennam, E. Susan. (1991). Grounding in communication. In Resnick, Lauren, Levine John, Teasley D. Stephanie (eds.). Perspectives on Socially Shared Cognition, 127-149. Washington: American Psychological Association.

Deacon, T. W. (1998). The Symbolic Species. The Co-evolution of Language and the Brain. New York - London: W.W. Norton.

Federici, S. (1970). Viet Cong Philosophy: Tran Duc Thao, Telos 6: 104-117.

Feron, A. (2014). Qui est Trần Đức Thảo? Vie et œvre d'un philosophe vietnamien. Contretemps, Blog. February, 5. http://www.contretemps. eu/interventions/qui-est-tr $\%$ E $1 \%$ BA $\%$ A 7 n- $\%$ C $4 \% 91 \%$ E $1 \% B B \% A 9 c-$ th $\%$ E1\%BA $\%$ A30\%C2\%A0-vie-\%C5\%93uvre-dun-philosophe-vietnamien.

Fitch W. T., Hauser D. M., Chomsky, N. (2005). The evolution of the language faculty: Clarifications and implications. Cognition 97: 179-210.

Harman, C. (1986). Base and Superstructure. International Socialism 2 (36): 3-44.

Hémery. D. (2013). Itinéraire I. Premier exil. In Benoist and Espagne 2013: 47-61.

Herrick, T. (2005). "A book which is no longer discussed today": Tran Duc Thao, Jacques Derrida, and Maurice Merleau-Ponty. Journal of the History of Ideas 66 (1): 113-131.

Jordan, A. Z. (1967). The Evolution of Dialectical Materialism. London: Macmillan.

Kerckhoven, G. (1985). Zur Genese des Begriffs 'Lebenswelt' bei Edmund Husserl. Archiv für Begriffsgeschichte 29: 182-203.

Gärdenfors, B. P. (2003). How Homo Became Sapiens. Oxford: University Press.

Giao, N. N. (1988). Ecrits et reperes biographiques. In Thảo (1988: 57-62).

Levin, R., Lewontin, R. (1985). The Dialectical Biologist. Boston: Harvard University Press.

Lieberman, P. (1984). The Biology and Evolution of Language. Cambridge: Harvard University Press.

McHale, S. (2002). Vietnamese Marxism, Dissent, and the Politics of Postcolonial Memory: Tran Duc Thao, 1946-1993. The Journal of Asian Studies 61 (1): 7-31.

Marx, K., Engels, F. [1845] 1989. Die Deutsche Ideologie. Kritik der neuesten deutschen Philosophie in ihren Repràsentanten Feuerbach, B. Bauer und 
Stirner, und des deutschen Soizalismus in seinen verschiedenen Propheten. MEW Bd. 3,11. Berlin: Karl Dietz Verlag.

Mithen, S. (2005). The singing Neanderthals. The Origins of Music, Language, Mind and Body. Harvard: University Press.

Osvath, P., Gärdenfors, B. P. (2005). Quand les hommes inventèrent l'avenir. Les Grands Dossiers des Sciences Humaines 12: 58-63.

Papin, P. (2013). Itinéraire 2. Les exils intérieurs. In Benoist, Espagne (eds.) (2013: 62-89).

Parent, T. (2013). Externalism and Self-Knowledge. The Stanford Encyclopedia of Philosophy (Summer 2013 Edition), Edward N. Zalta (ed.), (Available online: http://plato.stanford.edu/archives/sum2013/entries/self-knowledgeexternalism/).

Perreau, L. (2010). Le monde de la vie. In Benoist, J., Gérard, V. (eds.) Husserl, 251-272. Paris: Ellipses.

Pinker, S., Bloom, P. (1990). Natural language and natural selection. Behavioural and Brain Sciences 13 (4): 707-726.

Pinker, S., Jackendoff, R. (2005). The faculty of language: What's special about it? Cognition 95: 201-236.

Pleyer, M. (2011). The Biological Evolution of Language. Contributions to the Study of Language, Literature and Culture, 2011 (1): 75-97.

Reichenbach, H. (1947). Elements of Symbolic Logic. Dover: Macmillan Co.

Saussure, Ferdinand de. (1916). Cours de linguistique générale. Paris: Payot. English translation by Wade Baskin. (1959; 1995). Course in General Linguistics. New York: Columbia University Press.

Spelke, E. (1990). Principles of Object Perception. Cognitive Science 14 (1): 29-56.

Stout, D., Toth, N., Schick, K., Chaminade, T. (2008). Neural correlates of Early Stone Age toolmaking: technology, language and cognition in human evolution. Philosophical Transaction of Royal Society 363(1499): 1939-1949.

Thảo, T. Đ. (1951). Phénoménologie et Matérialisme Dialectique. Paris: Minh Tan. English trans. by D.J. Herman, D.V. Morano. (1985). Phenomenology and Dialectical Materialism. Boston Studies in the Philosophy of Science 49. Dordrecht Boston: D. Reidel.

Thảo, T. Đ. (1973). Recherches sur l'origine du langage et de la conscience. Paris: Editions Sociales. English trans. by Daniel J. Herman \& Robert L. Armstrong. (1984). Investigations into the origin of language and consciousness. Boston Studies in the Philosophy of Science 44. Dordrecht Boston: D. Reidel.

Thảo, T. Đ. (1974). De la phénoménologie à la dialectique matérialiste de la conscience (I). La Nouvelle Critique, 79-80 : 37-42.

Thảo, T. Đ. (1975). De la phénoménologie à la dialectique matérialiste de la conscience (II). La Nouvelle Critique 86: 23-29.

Thảo, Trần Đức. (1988). La Philosophie de Staline I. Paris: Editions May.

Thao, Van T. (2004). Les compagnons de route de Hô Chi Minh. Paris, Karthala.

Thao, Van T. (2013). Quelques jalons dans le parcours philosophique de Tran Duc Thao. In Benoist and Espage: 90-114. 
Thomas, P. 2008. Marxism and Scientific Socialism: From Engels to Althusser. London: Routledge.

Tomasello, M., Carpenter, M., Call, J., Behne, T., Moll, H. (2005). Understanding and sharing intentions: The origins of cultural cognition. Behvaioural and Brain Science 28 (5): 675-691.

Tomberg, F. (1969). Basis und Überbau. Sozialphilosophische Studien. Berlin: Neuwied.

Waldenfels, B. (1971). Weltliche und soziale Einzigkeit bei Husserl. Zeitschrift für philosophische Forschung, 25(2): 157-171. 